\title{
Reproductive biology of Synallaxis albescens (Aves: Furnariidae) in the cerrado of central Brazil
}

\author{
Miguel Ângelo Marini ${ }^{1,5}$, Sheila Silva Rodrigues ${ }^{2}$, Mariana Batista Silveira ${ }^{3}$ \& Harold Francis Greeney ${ }^{4}$ \\ ${ }^{1}$ Departamento de Zoologia, Instituto de Ciências Biológicas - IB, Universidade de Brasília - UnB, \\ Campus Universitário Darcy Ribeiro, CEP 70910-900, Brasilia, DF, Brasil \\ ${ }^{2}$ Programa de Pós-graduação em Biologia Animal, Instituto de Ciências Biológicas - IB, \\ Universidade de Brasília - UnB, Campus Universitário Darcy Ribeiro, CEP 70910-900, Brasília, DF, Brasil \\ ${ }^{3}$ Programa de Pós-graduação em Ecologia, Instituto de Ciências Biológicas - IB, Universidade de \\ Brasilia - UnB, Campus Universitário Darcy Ribeiro, CEP 70910-900, Brasília, DF, Brasil \\ ${ }^{4}$ Yanayacu Biological Station \& Center for Creative Studies, Cosanga, Ecuador, \\ clo Foch 721 y Amazonas, Quito, Ecuador \\ ${ }^{5}$ Corresponding author: Miguel Angelo Marini, e-mail: marini@unb.br
}

MARINI, M.Â., RODRIGUES, S.S., SILVEIRA, M.B. \& GREENEY, H.F. Reproductive biology of Synallaxis albescens (Aves: Furnariidae) in the cerrado of central Brazil. Biota Neotrop. 12(4): http://www. biotaneotropica.org.br/v12n4/en/abstract?short-communication+bn02212042012

Abstract: Understanding the causes and consequences of variation in reproductive strategies is a central theme in studies of avian life history evolution. This study describes the reproductive biology of Synallaxis albescens (Furnariidae) in the cerrado biome of central Brazil. We monitored 35 nests during the 2003 to 2011 breeding seasons, visiting them every 2-4 days. Synallaxis albescens breeds from mid-September to mid-January, builds a retort-shaped nest, and generally lays three immaculate white eggs. Eggs weighed $1.75 \mathrm{~g}$ and measured 19.7 by $14.4 \mathrm{~mm}$. Most nests studied were in open cerrado or shrub grassland at an average height above the ground of $0.3 \mathrm{~m}$, with a preference for Davilla elliptica (Dilleniaceae) shrubs as a nesting substrate. Incubation period averaged 18.1 days, while the nestling period averaged 13.6 days. Of 16 closely monitored nests, four were successful (25\%), 11 were depredated (69\%), and one was abandoned. Predation was similar during incubation (45\%) and nestling (55\%) phases. In general, the breeding biology of S. albescens was similar to that described previously for this species and for related Furnariidae.

Keywords: nests, eggs, reproduction, reproductive success.

MARINI, M.Â., RODRIGUES, S.S., SILVEIRA, M.B. \& GREENEY, H.F. Biologia reprodutiva de Synallaxis albescens (Aves: Furnariidae) em cerrado do Brasil central. Biota Neotrop. 12(4): http://www. biotaneotropica.org.br/v12n4/pt/abstract?short-communication+bn02212042012

Resumo: Um tema central em estudos acerca da evolução da história de vida de aves é o entendimento das causas e conseqüências da variação em estratégias reprodutivas. O presente estudo descreve a biologia reprodutiva de Synallaxis albescens (Furnariidae) no bioma cerrado do Brasil central. Nós monitoramos 35 ninhos durantes as estações reprodutivas de 2003 a 2011, visitando-os a cada 2-4 dias. Synallaxis albescens se reproduz da metade de setembro a metade de janeiro, constrói ninho em forma de retorta e geralmente coloca três ovos brancos. Os ovos apresentaram peso de 1,75g e medidas de 19,7 por 14,4 mm. A maior parte dos ninhos estudados estava em Campo sujo e Cerrado ralo a uma altura média, em relação ao solo, de $0.3 \mathrm{~m}$, com uma preferência por arbustos de Davilla elliptica (Dilleniaceae) como substrato para os ninhos. O período de incubação durou em média 18,1 dias, enquanto o período de permanência dos ninhegos durou em média 13,6 dias. Dos 16 ninhos monitorados, quatro obtiveram sucesso $(25 \%), 11$ foram predados $(69 \%)$ e um foi abandonado. A predação foi semelhante durante a fase de incubação $(45 \%)$ e durante a fase de cuidado dos ninhegos (55\%). Em geral, a biologia reprodutiva de $S$. albescens foi similar ao descrito previamente na literatura para esta espécie, bem como para Furnariidae relacionados.

Palavras-chave: ninhos, ovos, reprodução, sucesso reprodutivo. 


\section{Introduction}

Understanding the evolution of life history strategies is a central theme in ecology (Roff 1992, Stearns 1992, Ricklefs \& Wikelski 2002), particularly with birds (Ricklefs 1977, Martin 1987). Yet despite the fact that avian reproductive strategies provide model systems for developing evolutionary hypotheses (Martin 1995, 1996), testing phylogenetic relationships (Sheldon \& Winkler 1999, Zyskowski \& Prum 1999, Miller \& Greeney 2008), and developing sound conservation measures (Boyce 1992, Reed et al. 1998), we still know little about the basic reproductive biology of most tropical birds (Stutchbury \& Morton 2001) including Furnariidae (Remsen Junior 2003).

The genus Synallaxis includes 35 species of small furnariids (Passeriformes) which are distributed throughout Central and South America (Remsen Junior et al. 2012). Synallaxis spp. build large, bulky nests of twigs with an inner chamber lined with various soft materials and entered through a lateral tunnel (Vaurie 1980, Skutch 1996, Zyskowski \& Prum 1999, Remsen Junior 2003). Synallaxis albescens Temminck, 1823 is one of four Synallaxis species found in the Distrito Federal of central Brazil (Negret et al. 1984), where it inhabits open, sunny habitats such as campo cerrado (Vaurie 1980, Sick 1997, Fontana et al. 2003). Despite the fact that it is common within this part of its range (Negret et al. 1984), nothing has been published on its natural history in cerrado habitat, with most information derived from studies in other parts of its' range (Cruz \& Andrews 1989, Skutch 1996, Mezquida 2001). Here we describe the reproductive biology of $S$. albescens from the Brazilian cerrado, including seasonality, reproductive success, and nesting habitat.

\section{Materials and Methods}

We conducted our studies in the 10,500 ha reserve, Estação Ecológica de Águas Emendadas (ESECAE), Distrito Federal, Brazil

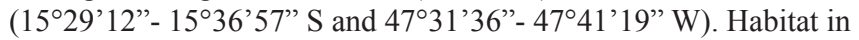
the reserve includes several cerrado vegetation types such as cerrado sensu stricto, shrub grassland, open cerrado and gallery forest (Silva Junior \& Felfili 1996). The Cerrado covers around 22\% of Brazil's land surface (approximately 1.8 million $\mathrm{km}^{2}$ sensu Smith 1998), is the second largest biome of South America (Ribeiro \& Walter 1998), and is the largest and most threatened tropical savanna in the world (Silva \& Bates 2002). It is the third richest Biome in bird species in the country, with 837 species (4.3\% endemic) (Cavalcanti 1999).

Data were collected from November 2003 to November 2011 in a demarcated area of $100 \mathrm{ha}(1 \mathrm{~km} \times 1 \mathrm{~km})$ and around it. We searched for nests by systematically inspecting the vegetation and by following the adults who showed evidence of reproductive activity (i.e., carrying material or food). After their initial discovery, we visited nests at intervals of 3-4 days, increasing visits to every 2 days during periods of expected laying, hatching, or fledging. At each visit we recorded the status (active, inactive) and contents (empty, eggs, nestlings). If a nest was encountered empty before the expected fledge date we described any evidence of predation or other disturbance. We considered nests successful when at least one of the chicks left the nest. If a nest was found empty after the minimum period for potential fledging and there was no evidence of predation we considered it successful. We considered as depredated those nests found intact but empty well before conclusion of the breeding cycle, those nests totally or partially destroyed on the ground or in situ, and those found with destroyed (or damaged) eggs or chicks killed by physical harm (i.e., not simply abandoned).

At accessible nests we recorded three external measurements $(\mathrm{cm})$ of nest architecture: the diameter of the main chamber, height of the main chamber, and length of the lateral entrance tube. We measured the maximum length and width of eggs to the nearest $0.1 \mathrm{~mm}$ using calipers with $0.05 \mathrm{~mm}$ precision and weighed them to the nearest $0.1 \mathrm{~g}$ using a scale accurate to $0.01 \mathrm{~g}$.

We define the incubation period as that between the last egg laying and hatching of the first, without considering the laying period. This was done since the only evidence of hatching patterns among Furnariidae is that eggs of the Rufous Hornero (Furnarius rufus Gmelin, 1788) hatch asynchronously (Remsen Junior 2003). We define the nestling period as the time between hatching of the first egg to fledging of the last chick from the nest (Robinson et al. 2000). All means are reported with $\pm \mathrm{SD}$ (standard deviation). We did not examine choice of nesting habitat, but only nesting habitat since we did not search equally for this species in all habitats. We considered all active and inactive nests found in the study area, including those found during construction but for which we did not observe a breeding attempt. We included in the analyses inactive nests since this is the only Synallaxis breeding in the study area and there is nothing known if Synallaxis builds dormitory-nests. At each nest we measured the height of each nest above ground $(\mathrm{m})$ with the aid of measuring tape. Nest plants were identified in the field or by comparison with plants from the herbarium at the Universidade de Brasília. Plant taxonomy follows Silva Junior (2005).

\section{Results and Discussion}

We found 35 S. albescens nests between 2003 and 2011. Despite year-round observations we recorded reproductive activity from September to January, including both the discovery of active nests and indirect evidence such as brood patches in adults. Extrapolating from these data we estimate that the earliest nesting attempts occurred during the last week of September $(n=2$, both during 2009 breeding season) when we registered the first egg laying and we estimate that the latest fledging occurred during the first week of January. We did not observe adults caught with mist-nets in reproductive condition after the last week of January. We captured six juveniles from November to March. In Argentina, S. albescens nests from November to March (Narosky et al. 1983, De la Peña 2005) later than at our study site. Strong nesting seasonality correlated with the rainy season has been documented for $S$. albescens in other parts of its range (Venezuela: Cruz \& Andrews 1989, Argentina: Mezquida 2001). Not surprisingly, breeding in our area also agrees with a variety of other cerrado species for which data are available (Alves \& Cavalcanti 1990, Marini \& Durães 2001, Lopes \& Marini 2005, Medeiros \& Marini 2007, França \& Marini 2009, Santos \& Marini 2010, Duca \& Marini 2011) and follows the general pattern of most neotropical species studied in habitats with strong seasonal shifts in rainfall (Marchant 1960, Ramo \& Busto 1984, Cruz \& Andrews 1989, Mezquida 2001, 2002).

Agreeing with previous nest descriptions for S. albescens (Vaurie 1980, Narosky et al. 1983, Cruz \& Andrews 1989, Skutch 1996, Mezquida 2001, Fontana et al. 2003, De la Peña 2005), and following the classification of Simon \& Pacheco (2005), all of the nests we observed were closed, retort-shaped masses of interwoven sticks enclosing an egg chamber entered from a lateral horizontal tube. The bottom portion of the inner chambers was lined with softer plant materials which frequently included pieces of snake skin and man-made materials (e.g., pieces of canvas, plastic tape, candy wrappers). We recorded the following measurements (see methods): external diameter $16 \mathrm{~cm}(\mathrm{n}=7)$; external height, $17 \mathrm{~cm}$ $(\mathrm{n}=6)$; entrance tunnel length, $11 \mathrm{~cm}(\mathrm{n}=7)$, which are slightly smaller than the ones reported by De la Peña (2005). Considering the relative uniformity of nest architecture in Synallaxis (Zyskowski \& Prum 1999, Remsen Junior 2003), it comes as no surprise that 
the nest of $S$. albescens is similar in form to those of its congeners (Skutch 1969, 1996, Narosky et al. 1983, Bosque \& Lentino 1987, De la Peña 1987, Simon \& Pacheco 1996, Sick 1997, Simon et al. 1999, Rubio \& Pinho 2008, Greeney 2009). At 16 nests mean clutch size was $2.6 \pm 0.6 \mathrm{eggs}$, a result similar to that of Mezquida (2001) $(2.7 \pm 0.3)$ but less than the 3 or 4 (Narosky et al. 1983, De la Peña 2005) or even 5 (Zuberbühler 1953) eggs reported for Argentina. We observed clutches of three eggs in $63 \%$ of nests $(n=10)$, two eggs in $31 \%$ of nests $(n=5)$ and found a single egg in only one nest. Eggs were white and long-oval in shape (after Podulka et al. 2004 classification). We were able to closely examine only two eggs (from the same clutch) which weighed, $1.8 \pm 0.2 \mathrm{~g}$ and had linear measurements of $19.7 \pm 0.1$ by $14.4 \pm 0.1 \mathrm{~mm}$, similar to values reported by De la Peña (2005). However, egg masses were lighter than the ones reported for Argentina which ranged from 2.0 to $2.4 \mathrm{~g}$ (Narosky et al. 1983). Though our sample size was low, egg measurements appear to be slightly smaller than previously reported (Haverschmidt 1968, Ffrench 1991), but within the range reported by Narosky et al. (1983). Average incubation period was $18.1 \pm 0.6(\mathrm{n}=5)$ days and the nestling period lasted $13.6 \pm 2.9(n=4)$ days, generally agreeing with other reports for this species (Ffrench 1991). In Argentina, De la Peña (2005) reported a 15-16 days of incubation period and 15 days of nestling period. Skutch (1996) reported that both parents incubate for 15-16 days. There also appears to be some variation in egg coloration within $S$. albescens. Reports from the southern portion of its range (De la Peña 1987, 2005, Mezquida 2001) describe eggs as greenish white, while in other areas they are described as immaculate white (Haverschmidt 1968, Ffrench 1991, this study). It remains to be seen to what extent color varies geographically for this species. A clutch of 2-3 eggs appears normal for the species throughout its range (Haverschmidt 1968, De la Peña 1987, Ffrench 1991, Skutch 1996, Geffen \& Yom-Tov 2000, Mezquida 2001), similar to most congeners (Remsen Junior 2003), but smaller than in Argentina (Narosky et al. 1983, De la Peña 2005).

Nests were built at an average height of $0.3 \pm 0.2 \mathrm{~m}(\mathrm{n}=30)$ above the ground, much lower than in Argentina (Narosky et al. 1983, Mezquida 2001, De la Peña 2005) and elsewhere in its range where it nests from 0.5 to $9 \mathrm{~m}$ (Skutch 1996). The shrub Davilla elliptica St. Hil. (Dilleniaceae) was the most commonly used substrate (44\%; $\mathrm{n}=15$ ). Five nests were built in grass clumps, four in different species of shrubs and over 10 in unidentified plant support. There are studies reporting preference of $S$. albescens by certain plants (Mezquida 2001, Fontana et al. 2003) as we found. The relative abundance of D. elliptica in our study area is $0.7 \%$ (Silva Junior \& Felfili, 1996), suggesting that the nests are being built at that plant with much more frequency than predicted by their availability in the environment, suggesting $S$. albescens would be classified as selective in their choice of substrate following the classification of Johnson (1980). We found nests in all four of the available vegetation types: grassland, shrub grassland, open cerrado and sparse savannah park. However, we found most nests in shrub grassland (42.9\%) and open cerrado $(34.3 \%)$, with the remainder in park savannah $(14.3 \%)$ and grassland $(8.6 \%)$.

Of 16 nests which were monitored closely, 11 (69\%)were depredated, four fledged (25\%), and one was abandoned during incubation $(6 \%)$. Additionally, one nest failed due to interference from the observer and one was collected during incubation. Synallaxis brachyura (Lafresnaye, 1843) from Costa Rica also fledged young from only $23 \%$ of the nests (Skutch 1996). Predation has been indicated as the main factor in brood loss for several species of tropical regions (Aguilar et al. 1999, Stutchbury \& Morton 2001, Rubio \& Pinho 2008, Duca \& Marini 2011). Of the total nests depredated, $45 \%$ were in egg stage and 55\% at the nestling stage. Predation rates are often highest during the nestling phase because, in general, at this stage predators are guided by the movement of adults to feed the chicks (Slagsvold 1982). Straneck (1999) suggested that the begging call of $S$. albescens nestlings mimics the mechanical sound of the rattlesnake to avoid predation.

This study is the first to detail several aspects of the reproduction of this species in the cerrado environment. It revealed some different breeding aspects, such as nest size and placement, egg color, compared to other populations. In addition it improves the knowledge of breeding of birds in the cerrado, a region in face of rapid and wide transformation.

\section{Acknowledgements}

This study was partially funded by research grants from $\mathrm{CNPq}$, FAP-DF, Pós-graduação em Ecologia e Pós-graduação em Biologia Animal (UnB), FINATEC, FUNPE, and Neotropical Grassland Conservancy. We would like to thank CNPq for a Research Fellowship to MÂM, and CAPES for Student Fellowship to SSR and MBS. We are grateful to ESECAE (GDF-DF) for allowing this study on their area and to the colleagues that helped during data collection.

\section{References}

AGUILAR, T.M., LEITE, L.O. \& MARINI, M.Â. 1999. Biologia da nidificação de Lathrotriccus euleri (Cabanis, 1968) (Tyrannidae) em fragmentos de mata de Minas Gerais. Ararajuba, Rev. Bras. Ornitol. 7:125-133.

ALVES, M.A.S. \& CAVALCANTI, R.B. 1990. Ninhos, ovos e crescimento de filhotes de Neothraupis fasciata. Ararajuba, Rev. Bras. Ornitol. 1:91-94.

BOSQUE, C. \& LENTINO, M. 1987. The nest, eggs, and young of the White-whiskered Spinetail (Synallaxis [Poecilurus] candei). Wilson Bull. 99:104-106.

BOYCE, M.S. 1992. Population viability analysis. Annu. Rev. Ecol. Syst. 23:481-506. http://dx.doi.org/10.1146/annurev.es.23.110192.002405

CAVALCANTI, R.B. 1999. Bird species richness and conservation in the cerrado region of central Brazil. Stud. Avian Biol. 19:244-249.

CRUZ, A. \& ANDREWS, R.W. 1989. Observations on the breeding biology of passerines in a seasonally flooded savanna in Venezuela. Wilson Bull. 101:62-76.

DE LA PEÑA, M.R. 1987. Nidos y huevos de aves argentinas. Edited by the author, Santa Fe.

DE LA PEÑA, M.R. 2005. Reproducción de las aves argentinas (con descripción de pichones). Monografia 20, L.O.L.A., Buenos Aires.

DUCA, C. \& MARINI, M.Â. 2011. Variation in breeding of the Shrike-like Tanager in central Brazil. Wilson J. Ornithol. 123:259-266. http://dx.doi. org/10.1676/10-116.1

FFRENCH, R. 1991. A guide to the birds of Trinidad \& Tobago. Comstock Publishing Associates, Ithaca.

FONTANA, C.S., BENCKE, G.A. \& REIS, R.E. 2003. Livro Vermelho da Fauna Ameaçada de Extinção no Rio Grande do Sul. EDIPUCRS, Porto Alegre.

FRANÇA, L. F. \& MARINI, M. Â. 2009. Low and variable reproductive success of a Neotropical flycatcher (Suiriri islerorum). EMU 109:265-269. http://dx.doi.org/10.1071/MU09052

GEFFEN, E. \& YOM-TOV, Y. 2000. Are incubation and fledging periods longer in the tropics? J. Anim. Ecol. 69:59-73. http://dx.doi.org/10.1046/ j.1365-2656.2000.00370.x

GREENEY, H.F. 2009. The nest, egg, and nestling of the dusky Spinetail (Synallaxis moesta) in eastern Ecuador. Ornitol. Neotrop. 20:153-156.

HAVERSCHMIDT, F. 1968. The birds of Suriname. Oliver \& Boyd, London.

JOHNSON, D.H. 1980. The comparison of usage and availability measurements for evaluating resource preference. Ecology 61:65-71. http://dx.doi.org/10.2307/1937156 
LOPES, L.E. \& MARINI, M.Â. 2005. Biologia reprodutiva de Suiriri affinis e $S$. islerorum (Aves: Tyrannidae) no Cerrado do Brasil Central. Pap. Avul. Zool. 45(12):127-141.

MARCHANT, S. 1960. The breeding of some S. W. Ecuadorian birds. Ibis 102:584-599. http://dx.doi.org/10.1111/j.1474-919X.1960.tb07134.x

MARINI, M.Â. \& DURÃES, R. 2001. Annual patterns of molt and reproductive activity of passerines in south-central Brazil. Condor 103:767-775. http://dx.doi.org/10.1650/0010-5422(2001)103[0767:AP OMAR]2.0.CO;2

MARTIN, T.E. 1987. Food as a limit on breeding birds: A life-history perspective. Annu. Rev. Ecol. Syst. 18:453-487. http://dx.doi.org/10.1146/ annurev.es.18.110187.002321

MARTIN, T.E. 1995. Avian life history evolution in relation to nest sites, nest predation and food. Ecol. Monogr. 65:101-127. http://dx.doi. org $/ 10.2307 / 2937160$

MARTIN, T.E. 1996. Life history evolution in tropical and south temperate birds: what do we really know? J. Avian Biol. 27:263-272. http://dx.doi. org $/ 10.2307 / 3677257$

MEDEIROS, R.C.S. \& MARINI, M.Â. 2007. Biologia reprodutiva de Elaenia chiriquensis (Lawrence, 1865) (Aves: Tyrannidae) em Cerrado do Brasil Central. Rev. Bras. Zool. 24:12-20. http://dx.doi.org/10.1590/ S0101-81752007000100002

MEZQUIDA, E.T. 2001. La reproducción de algunas especies de Dendrocolaptidae y Furnariidae en el desierto del Monte central, Argentina. Hornero 16:23-30.

MEZQUIDA, E.T. 2002. Nidificación de ocho especies de Tyrannidae en la Reserva de Ñacuñán, Mendoza, Argentina. Hornero 17:31-40.

MILLER, E.T. \& GREENEY, H.F. 2008. Clarifying the nest architecture of the Silvicultrix clade of Ochthoeca chat-tyrants (Tyrannidae). Ornitol. Neotrop. 19:361-370.

NAROSKY, S., FRAGA, R. \& DE LA PEÑA, M. 1983. Nidificación de las aves argentinas (Dendrocolaptidae y Furnariidae). Asociación Ornitológica del Plata, Buenos Aires.

NEGRET, A., TAYLOR, J., SOARES, R.C., CAVALCANTI, R.B. \& JOHNSON, C. 1984. Aves da região geopolítica do Distrito Federal. Lista (check list) 429 espécies. SEMA, Brasília.

PODULKA, S., ROHRBAUGH JUNIOR, R.W., \& BONNEY, R. (Eds.) 2004. Handbook of Bird Biology. The Cornell Lab of Ornithology, Ithaca.

RAMO, C. \& BUSTO, B. 1984. Nidificación de los Passeriformes en los Llanos de Apure (Venezuela). Biotropica 16:59-68. http://dx.doi. org $/ 10.2307 / 2387896$

REED, J.M., ELPHICK, C.S. \& ORING, L.W. 1998. Life-history and viability analysis of the endangered Hawaiian Stilt. Biol. Conserv. 84:35-45. http:// dx.doi.org/10.1016/S0006-3207(97)00077-3

REMSEN JUNIOR, J.V. 2003. Family Furnariidae (Ovenbirds). In Handbook of the birds of the world (J. del Hoyo, A. Elliott \& D. Christie, eds). Lynx Edicions, Barcelona, v.8: Broadbills to Tapaculos, p.162-357.

REMSEN JUNIOR, J.V., CADENA, C.D., JARAMILLO, A., NORES, M., PACHECO, J.F., PÉREZ-EMÁN, J., ROBBINS, M.B., STILES, F.G. STOTZ, D.F. \& ZIMMER, K.J. 2012. A classification of the bird species of South America. American Ornithologists' Union. http://www.museum. lsu.edu/ Remsen/SACCBaseline.html.

RIBEIRO, J.F. \& WALTER, B.M.T. 1998. Fitofisionomias do bioma Cerrado. In Cerrado: ambiente e flora (S.M. Sano \& S.P.D. Almeida, eds). EmbrapaCPAC, Brasília, p.89-166.

RICKLEFS, R.E. 1977. On the evolution of reproductive strategies in birds: reproductive effort. Am. Nat. 111:453-478. http://dx.doi. org $/ 10.1086 / 283179$
RICKLEFS, R.E. \& WIKELSKI, M. 2002. The physiology/life history nexus. Trends Ecol. Evol. 17:462-168. http://dx.doi.org/10.1016/S01695347(02)02578-8

ROBINSON, W.D., ROBINSON, T.R., ROBINSON, S.K. \& BRAWN, J.D. 2000. Nesting success of understory forest birds in Central Panama. J. Avian Biol. 31:151-164. http://dx.doi.org/10.1034/j.1600048X.2000.310207.x

ROFF, D.A. 1992. The evolution of life histories: Theory and analysis. Chapman and Hall, New York.

RUBIO, T.C. \& PINHO, J.B. 2008. Biologia reprodutiva de Synallaxis albilora (Aves: Furnariidae) no Pantanal de Poconé, Mato Grosso. Pap. Avulsos Zool. 48(17):181-197.

SANTOS, L.R. \& MARINI, M.Â. 2010. Breeding biology of the White-rumped Tanager (Cypsnagra hirundinacea) in central Brazil. J. Field Ornithol. 81:252-258. http://dx.doi.org/10.1111/j.1557-9263.2010.00280.x

SICK, H. 1997. Ornitologia brasileira. Nova Fronteira, Rio de Janeiro.

SILVA, J.M.C. \& BATES, J.M. 2002. Biogeographic patterns and conservation in the South American Cerrado: A tropical savanna hotspot. BioScience 52:225-234. http://dx.doi.org/10.1641/0006-3568(2002)052[0225:BPA CIT]2.0.CO;2

SILVA JUNIOR, M.C. 2005. 100 árvores do Cerrado: guia de campo. Rede Sementes do Cerrado, Brasília.

SILVA JUNIOR, M.C. \& FELFILI, J.M. 1996. A vegetação da Estação Ecológica de Águas Emendadas. SEMATEC, IEMA, IBAMA, Brasília.

SIMON, J.E. \& PACHECO, S. 1996. Nidificação de Synallaxis cinerascens (Aves, Furnariidae) no estado de Minas Gerais. Rev. Bras. Biol. 56:585-590.

SIMON, J.E. \& PACHECO, S. 2005. On the standardization of nest descriptions of neotropical birds. Rev. Bras. Ornitol., Ararajuba 13:143-154.

SIMON, J.E., PACHECO, S. \& SILVA, N.F. 1999. Descrição do ninho de Synallaxis ruficapilla Vieillot, 1819 (Aves: Furnariidae). Ararajuba, Rev. Bras. Ornitol. 7:145-148.

SKUTCH, A.F. 1969. Life histories of Central American birds III - Families Cotingidae, Pipridae, Formicariidae, Furnariidae, Dendrocolaptidae, and Picidae. Cooper Ornithological Society, Berkeley.

SKUTCH, A.F. 1996. Antbirds \& ovenbirds. University of Texas Press, Austin.

SLAGSVOLD, T. 1982. Clutch size variation in Passerine birds: The nest predation hypothesis. Oecologia 54:159-169. http://dx.doi.org/10.1007/ BF00378388

STEARNS, S.C. 1992. The evolution of life histories. Oxford University Press, Oxford.

STRANECK, R.J. 1999. Una vocalización del Pijuí Común de Cola Parda, Synallaxis albescens (Aves, Furnariidae), es similar al sonido mecánico de advertencia de la Víbora de Cascabel, Crotalus durissus terrificus (Serpentes, Crotalidae). Rev. Mus. Argent. Cienc. Nat. 1(1):115-119.

STUTCHBURY, B.M. \& MORTON, E.S. 2001. Behavioral ecology of tropical birds. Academic Press, San Diego.

VAURIE, C. 1980. Taxonomy and geographical distribution of the Furnariidae (Aves, Passeriformes). B. Am. Mus. Nat. Hist. 166:1-357.

ZYSKOWSKI, K. \& PRUM, R.O. 1999. Phylogenetic analysis of the nest architecture of Neotropical ovenbirds (Furnariidae). Auk 116:891-911. http://dx.doi.org/10.2307/4089670

ZUBERBÜHLER, E.A. 1953. Notas para la biografía del pijuí de pecho blanco. Hornero 10:78-79. 